\title{
Ice sheet collapse following a prolonged period of stable sea level during the last interglacial
}

\author{
Michael J. O'Leary ${ }^{1 \star}$, Paul J. Hearty ${ }^{2}$, William G. Thompson ${ }^{3}$, Maureen E. Raymo ${ }^{4}$, Jerry X. Mitrovica ${ }^{5}$ \\ and Jody M. Webster 6
}

During the last interglacial period, 127-116 kyr ago, global mean sea level reached a peak of 5-9 m above present-day sea level. However, the exact timing and magnitude of ice sheet collapse that contributed to the sea-level highstand is unclear. Here we explore this timing using stratigraphic and geomorphic mapping and uranium-series geochronology of fossil coral reefs and geophysical modelling of sea-level records from Western Australia. We show that between 127 and 119 kyr ago, eustatic sea level remained relatively stable at about 3-4 m above present sea level. However, stratigraphically younger fossil corals with U-series ages of $118.1 \pm 1.4 \mathrm{kyr}$ are observed at elevations of up to $9.5 \mathrm{~m}$ above present mean sea level. Accounting for glacial isostatic adjustment and localized tectonics, we conclude that eustatic sea level rose to about $9 \mathrm{~m}$ above present at the end of the last interglacial. We suggest that in the last few thousand years of the interglacial, a critical ice sheet stability threshold was crossed, resulting in the catastrophic collapse of polar ice sheets and substantial sea-level rise.

O scillations of sea level, whether rapid or gradual, influence the degree and style of reef framework construction, destruction and preservation. Therefore, understanding the geomorphic response of coral reefs and associated sedimentary deposits to evolving sea-level-controlled environmental settings is essential for reconstructing past sea level. Estimating past eustatic sea level (ESL; or, equivalently, ice volume) also requires identification of the tectonic and glacio-isostatic contributions to local sea-level change. Although tectonic effects are a relatively local phenomenon, glacial isostatic adjustment (GIA) is characterized by broad regional patterns that vary systematically around the globe $\mathrm{e}^{1-3}$. The GIA contribution to interglacial sea level at most sites in the far field of the late Pleistocene ice mass centres (for example, Western Australia) will be an early sea-level peak, followed by a slow regression associated with the combined effects of ocean syphoning and continental levering ${ }^{4}$.

Here we present a comprehensive database of geographically distributed and well-dated last interglacial shoreline elevations between Cape Vlaming $\left(21.75^{\circ} \mathrm{S}\right)$ and Cape Leeuwin $\left(34.5^{\circ} \mathrm{S}\right)$, Western Australia (Supplementary Information SD1). Using this database, combined with geophysical modelling, we separate timevarying differences in ice volumes, relative to the present day, from syn- and post-depositional effects associated with tectonism and GIA, to robustly constrain the timing of ice sheet collapse during marine isotope stage (MIS) 5e.

A total of 13 new and 15 previously published MIS 5e palaeoshoreline sites were surveyed within six geologically distinct regions along the Western Australia coastline (Supplementary Fig. S1). Shoreline elevation data were compiled from geomorphic features (emergent fringing reefs and shore platforms), sedimentary deposits (peritidal marine sands and eolianites) and palaeocological associations (corals and coralline algae), all of which form at a known position or depth range relative to mean sea level (MSL). We document two geomorphically distinct MIS 5e marine highstand units: a lower, broad, erosional fringing reef (similar to what is observed offshore today) that outcrops intermittently along the Western Australia coast at elevations of between +1.9 and $+3.6 \mathrm{~m}$ above MSL; and an upper, stratigraphically younger constructional reef found at elevations of between +3.5 and $+9.5 \mathrm{~m}$ above MSL. The two reef units are commonly separated by an unconformity surface or palaeosol. A total of 17 new (open-system-corrected) and 82 previously published U-series coral dates (see ref. 5 for summary) constrain the timing of coral reef development.

\section{Establishing a palaeoMSL datum}

The lower reef terraces are characterized by an erosional, quasihorizontal shore platform that forms its upper surface. The development of such a surface is typically the result of either wave abrasion in the shallow subtidal to lower intertidal zone and/or bioerosion and chemical weathering that is usually more aggressive within the middle to upper intertidal zone. Typically, mature shore platforms are assumed to occupy the level of the mean low low water (MLLW) tide level although a survey of modern shore platforms in this region shows elevations ranging up to +0.7 above the MLLW level (Fig. 1a,b). This finding supports a recent study ${ }^{6}$ that showed shore platform elevations relative to MSL are dependent on: the rate of vertical weathering; exposure to wave energy; nearshore water depth; and rock resistance. To assume a MLLW elevation for a fossil shore platform when inferring local palaeoMSL is to introduce a potential error of up to $+0.7 \mathrm{~m}$ (for Western Australia).

To avoid incorporating this error into our palaeoMSL calculations, we first measured the elevation, relative to MSL, of modern biological communities and geomorphic features at each of our field sites, noting prevailing physical parameters including wave

\footnotetext{
${ }^{1}$ Department of Environment \& Agriculture, Curtin University, Bentley, Western Australia 6102, Australia, ${ }^{2}$ Department of Environmental Studies, University of North Carolina, Wilmington, North Carolina 28403, USA, ${ }^{3}$ Department of Geology \& Geophysics, Woods Hole Oceanographic Institution, Woods Hole, Massachusetts 02543, USA, ${ }^{4}$ Lamont-Doherty Earth Observatory, Columbia University, Palisades, New York 10964, USA, ${ }^{5}$ Department of Earth and Planetary Sciences, Harvard University, Cambridge, Massachusetts 02138, USA, ${ }^{6}$ Geocoastal Research Group, School of Geosciences, The University of Sydney, New South Wales, 2006, Australia. *e-mail: mick.oleary@curtin.edu.au
} 


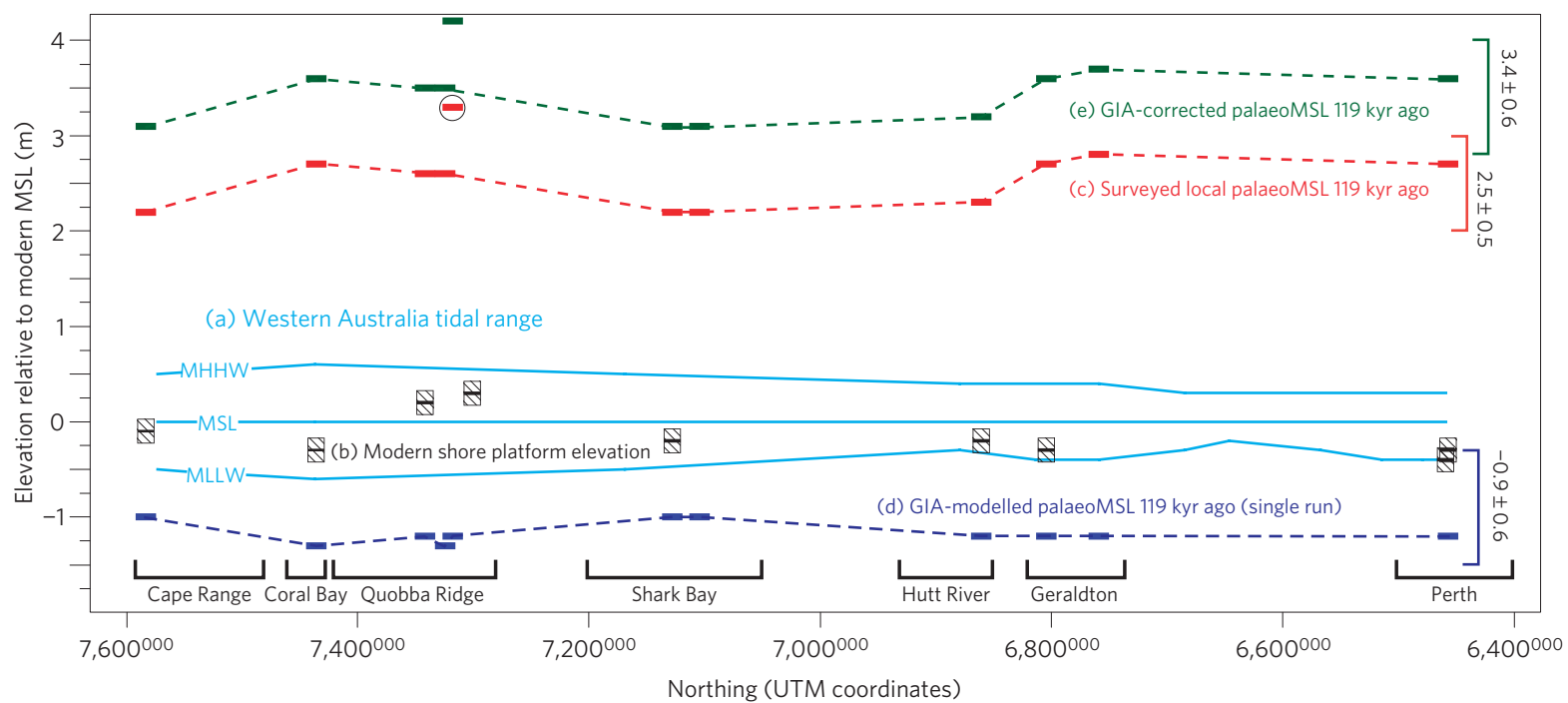

Figure 1 | Elevation of modern and MIS 5e sea-level indicators above a modern MSL datum for sites between Cape Vlaming and Rottnest Island. a, The light blue lines represent the modern MSL datum, mean high high water (MHHW) and mean low low water (MLLW) levels. South Western Australia is characterized by a diurnal microtidal environment with a maximum tidal range of $1.2 \mathrm{~m}$. $\mathbf{b}$, Hatched bars represent the inner margin elevation of the modern shore platforms, which vary from $-0.4 \mathrm{~m}$ below to $+0.3 \mathrm{~m}$ above MSL (height of each bar represents the survey errors). c, Red bars represent palaeoMSL $119 \mathrm{kyr}$ ago, calculated by adding/subtracting the offset of the modern shore platform from modern MSL to the observed elevation of the palaeoplatform (mean value $=2.5 \pm 0.5 \mathrm{~m}$; the Cape Cuvier observation at $+3.3 \mathrm{~m}$, circled red bar, was excluded from the calculation). d, Blue bars represent GIA predictions (single run) of relative sea level $119 \mathrm{kyr}$ ago, assuming that ice volumes during MIS $5 \mathrm{e}$ were the same as today (see Methods). The mean of numerous GIA simulations is $-0.9 \pm 0.6 \mathrm{~m}$ (see text). e, GIA-corrected palaeoMSL for Western Australia (3.4 \pm 0.6 ) is the total vertical distance between the surveyed local palaeoMSL datum c and the Holocene equivalent 119-kyr-old shoreline $(-0.9 \pm 0.6 \mathrm{~m} ; \mathbf{d})$, measured from modern MSL.

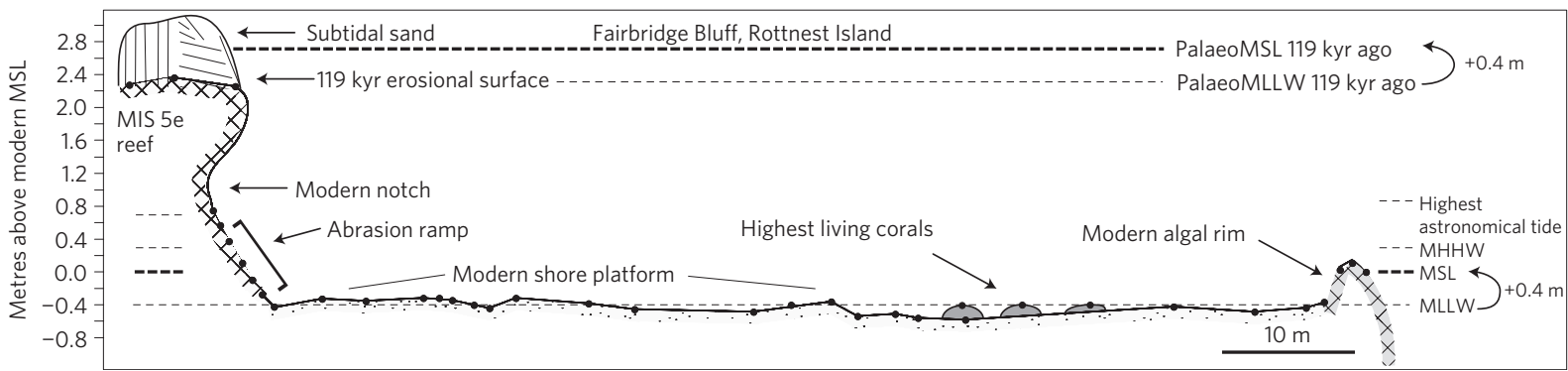

Figure 2 | Surveyed cross-section at Fairbridge Bluff, Rottnest Island. Each of the black dots represents an Omnistar survey point. The lower modern shore platform has an elevation of -0.3 to $-0.4 \mathrm{~m}$ below MSL; an algal ridge on the seaward margin rises to MSL. The highest living corals are found at the level of MLLW. At the inner margin, an abrasion ramp rises to a modern erosional notch found at the level of highest astronomical tide. A $2.4-\mathrm{m}$-high shore platform formed at the level of palaeoMLLW and palaeoMSL is calculated to be $0.4 \mathrm{~m}$ above this datum.

energy, rock type and tidal range (SD1). We then take the observed position of the modern sea-level indicator relative to modern MSL and apply this offset to the adjacent MIS 5e biological community or geomorphic feature to estimate the position of palaeoMSL at the time these features were forming (Fig. 2). We thus establish an accurate and locally appropriate palaeoMSL datum for each of the surveyed MIS 5e sites. In 10 of the 11 MIS 5e sites that exhibit distinct shore platform morphology, the inferred palaeoMSL datum varied in elevation from +2.2 to $+2.8 \mathrm{~m}$ above the modern MSL datum (red bars in Fig. 1c; mean value $+2.5 \pm 0.5 \mathrm{~m}$ ). A higher value of $+3.3 \mathrm{~m}$ is inferred at Cape Cuvier (circled red bar in Fig. 1c). To explain the observed variability in the palaeoMSL benchmarks, it is first necessary to establish shore platform age along the coast of Western Australia.

The geomorphic response of shore platforms to sea-level change is slow and muted, recording only the broad brushstroke of sea-level highs and lows ${ }^{7}$. So, just as modern-day shore platforms in Western Australia evolved during gradually falling sea level over the last $6 \mathrm{kyr}$ of the Holocene, MIS 5e shore platforms that formed over the duration of the MIS 5e highstand should also represent sea level during the final stages of that extended interval of gradual sea-level fall. A precise age for the end of platform formation is constrained by the age of the youngest corals forming the lower reef platform as well as the first occurrence of corals that later colonized this surface (which would indicate a subsequent sea-level-rise event). A total of 60 open-system-corrected U-series coral dates confirm that an extended interval of reef growth and shore platform development occurred between 127 and 119 kyr ago (Fig. 3, SD1). U-series dates also show that the earliest occurrence of flooding and establishment of coral growth on the shore platform took place at around $119.5 \mathrm{kyr}$ ago, an event that could have been caused only by a pronounced late MIS 5e sea-level rise (Fig. 3). Published dates from the Bahamas ${ }^{8}$ suggest that a similar interval of reef growth over an existing shore platform occurred $119.2 \pm 0.5 \mathrm{kyr}$ ago.

\section{Correcting palaeoMSL for GIA}

Having established a mean palaeoMSL datum of $+2.5 \pm 0.5 \mathrm{~m}$ above present MSL $119 \mathrm{kyr}$ ago (constrained by the age of the youngest corals forming the lower reef platform), we now have a reference 


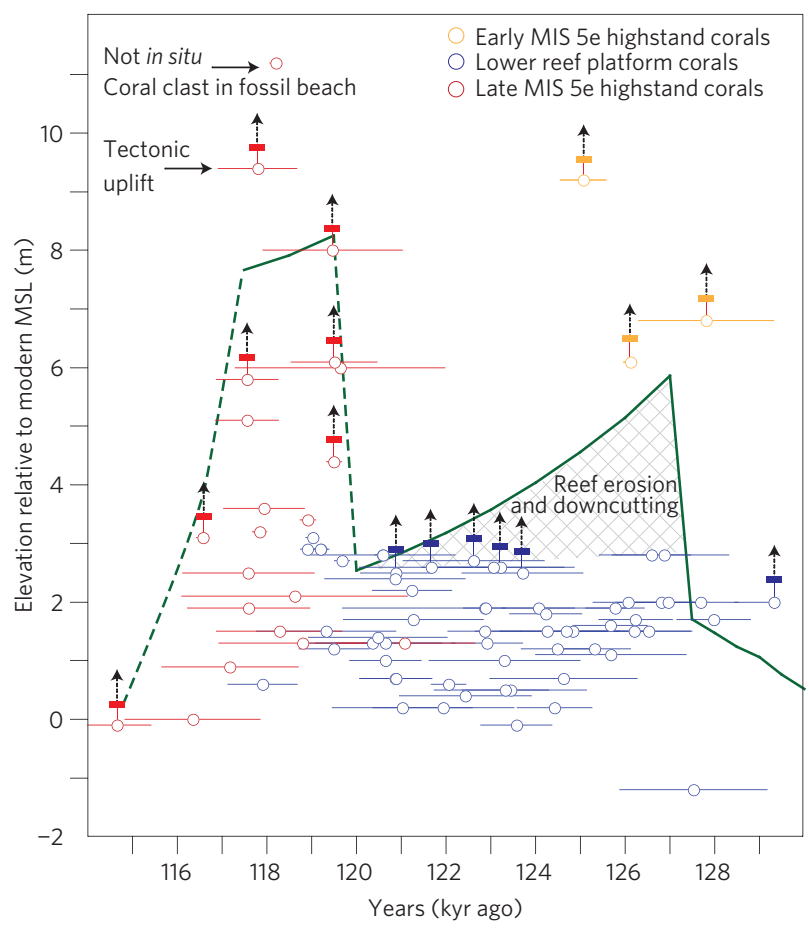

Figure 3 | Relative sea-level curve for Western Australia. A geomorphically defined palaeoMSL datum of $+2.5 \mathrm{~m} 120 \mathrm{kyr}$ ago (Fig. 1c) anchors a predicted relative sea-level curve at Red Bluff, which includes a GIA signal based on the test calculation (see Methods) plus the following ESL history: ESL jumps from 0 to $3.4 \mathrm{~m}$ between $127.5 \mathrm{kyr}$ and $127 \mathrm{kyr}$ ago and remains at this level until $120 \mathrm{kyr}$ ago; and $120 \mathrm{kyr}$ ago, ESL jumps $\sim 6 \mathrm{~m}$ over $1 \mathrm{kyr}$. Dashed green line is an inferred sea-level curve based on a minimum coral palaeodepth (solid bar above circle) of $0.4 \mathrm{~m}$ below palaeoMSL. This palaeodepth calculation is applicable only to highest in situ corals, as corals of the same age found at lower elevations will have a known water depth of at least up to the height of the coral above it. Arrows indicate potential for greater palaeodepth range.

datum with which to model regional sea-level changes owing to GIA. Our test GIA simulation (see Methods) incorporates the last two glacial cycles, timed to be consistent with the known duration of MIS 5e in Western Australia; the first cycle (MIS 6) ending $127 \mathrm{kyr}$ ago and the second (MIS 5d) starting $116 \mathrm{kyr}$ ago (that is, giving an $11 \mathrm{kyr}$ duration for MIS 5e). These calculations assume that the ice volume during the last interglacial was the same as at present day; thus, any observed departure from the predicted GIA signal may be ascribed to a change in ice volume relative to today.

Along the coast of Western Australia at least two distinct physical processes contribute to the GIA signal ${ }^{5,9}$. The first, continental levering, results in the uplift of continents and subsidence of offshore oceanic regions driven by meltwater loading ${ }^{3,10}$. The second, ocean syphoning, lowers sea level throughout the entire region as water migrates away from the far field of the late Pleistocene ice sheets to fill accommodation space created by the subsidence of the peripheral bulges that encircle areas of recent glaciation and oceanic regions subject to levering ${ }^{3}$. The net effect of these two processes on the surveyed section of Western Australia coast during any interglacial period is the predicted development of a sea-level highstand at the start of the interglacial period, followed by a monotonic fall in sea level (refs 9,11; see green line between 127 and $120 \mathrm{kyr}$ ago in Fig. 3 and Supplementary Fig. S2). As these GIA processes have acted for only $6 \mathrm{kyr}$ during the present interglacial rather than for the $\sim 8 \mathrm{kyr}$ span (127-119 kyr ago) during our model MIS 5e, and in the absence of any difference in ice volume during MIS 5e relative to today, the shoreline of $119 \mathrm{kyr}$ ago would be

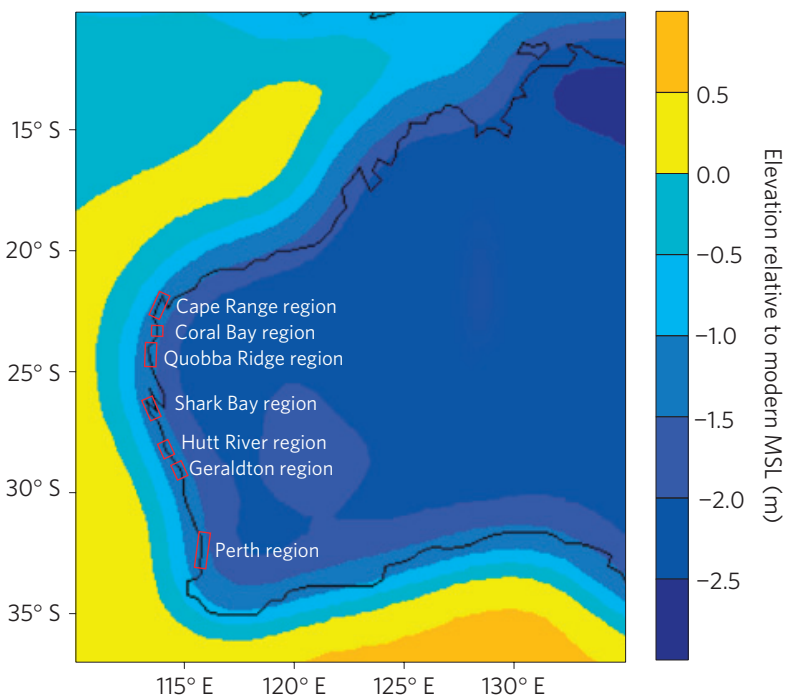

Figure 4 | GIA correction near the end of MIS 5e for Western Australia.

Sea level 119 kyr ago relative to the present day owing to GIA. The prediction adopts the two glacial cycle ice history and viscoelastic Earth model described in the Methods. This ice history assumes that ice volumes during MIS $5 \mathrm{e}$ were the same as during the present interglacial and therefore the prediction is the result of GIA alone, with no contribution from a difference in ice volumes between MIS $5 \mathrm{e}$ and present.

predicted to outcrop below the present intertidal zone (Fig. 1d and Supplementary Fig. S2).

Although the local palaeoMSL data inferred from each of the surveyed MIS 5e sites ranged between +2.2 and $+3.3 \mathrm{~m}$ above MSL (Fig. 1c), our test GIA simulation (see Methods) predicted a shoreline with elevations that ranged between -1.0 and $-1.3 \mathrm{~m}$ below MSL $119 \mathrm{kyr}$ ago (Fig. 1d). The narrow elevation range of the modelled GIA shoreline suggests a fairly uniform levering signal along the Western Australia coast and provides a relative benchmark with which to evaluate non-GIA post-depositional movement of MIS $5 \mathrm{e}$ shorelines. As we have noted, 10 of the 11 surveyed MIS 5e sites record elevations ranging between +2.2 and $+2.8 \mathrm{~m}$, suggesting almost no post-depositional tectonic movement at these sites. The palaeoMSL elevation of +3.3 at Cape Cuvier is slightly higher, suggesting the possibility that minor $(\sim 1.0 \mathrm{~m})$ post-depositional uplift may have occurred at this site since the last interglacial. Given the absence of evidence for substantial tectonic uplift or subsidence, we can assume that the observed difference between the modelled GIA shorelines and the palaeoMSL data for $119 \mathrm{kyr}$ ago represents the difference in ESL during MIS 5e compared with today.

Having calculated only minor latitudinal variability in the GIA signal along the Western Australia coast, we next test the sensitivity of the GIA predictions to changes in Earth model parameters. We repeated the calculations in Fig. 1d for a suite of simulations in which we considered the following parameter variations: elastic lithospheric thicknesses of 45-95 km, upper mantle viscosities of $1-5 \times 10^{20} \mathrm{~Pa}$ and lower mantle viscosities of $3-30 \times 10^{21} \mathrm{~Pa}$ s. For each of these model runs, we computed the mean GIA correction along the surveyed profile. The average of these corrections, with two-sigma uncertainty range, is $-0.9 \pm 0.6 \mathrm{~m} 119 \mathrm{kyr}$ ago (Fig. 1d). Combining this GIA correction with the mean elevation of the ten sites discussed above $(2.5 \pm 0.5 \mathrm{~m})$ yields a GIA-corrected mean elevation of MSL of $3.4 \pm 0.6 \mathrm{~m}$ (Fig. 1e). We also note that varying the end time of the MIS 6 deglaciation by \pm 3 kyr perturbed the GIA correction $119 \mathrm{kyr}$ ago by $\sim \pm 0.5 \mathrm{~m}$.

We estimate that a $3.4 \mathrm{~m}$ (GIA corrected) sea-level highstand along the coast of Western Australia $119 \mathrm{kyr}$ ago would require 
a eustatic melt event $127 \mathrm{kyr}$ ago of either $3.1 \mathrm{~m}$ from West Antarctica or $3.9 \mathrm{~m}$ from the Greenland Ice Sheet (Supplementary Information). Of course, both ice sheets, together with the East Antarctic Ice Sheet and mountain glaciers, may have contributed to the MIS 5e sea level from 127 to $119 \mathrm{kyr}$ ago and thus the net eustatic value of the melting of Greenland and West Antarctica was likely to have been intermediate to these values. Furthermore, a recent analysis suggests a global mean contribution of $0.4 \pm 0.3 \mathrm{~m}$ from the steric effect of ocean thermal expansion to MIS 5e sea level (ref. 12). Thus, the geomorphic and U-series evidence presented here, as well as uncertainties in various signals noted above, indicate that ESL during the period from 127 to $119 \mathrm{kyr}$ ago was characterized by relative sea-level stability around a mean of $\sim 3.5 \mathrm{~m}$.

\section{A late MIS $5 e$ rise in sea level}

Next, we turn to the higher MIS 5e marine unit. Although this unit is found across the southwest coast, it is best represented along the 150-km-long Miocene Quobba Ridge, where it is characterized by a reef framestone rising to an elevation of 5-6 $\mathrm{m}$. At this level it grades out landwards into a $10-20$ - $\mathrm{cm}$-thick veneer of coralline algal bindstone with isolated encrusting corals found at elevations of up to $+9.4 \mathrm{~m}$. These higher marine formations exhibit an irregular surface topography with corals expressing their primary growth morphology; this implies that, unlike the shore platform of the lower reef terrace, the primary constructional reef morphology has been preserved. Although corals are generally poor indicators of palaeodepth, they can, when placed in a stratigraphic or geomorphic context, provide a reasonably accurate assessment of the position of MSL. Modern living reef platform corals were found to grow in water depths ranging from MLLW up to the level of MSL in very high-energy environments. For MIS 5 e reef flat corals we apply a minimum palaeodepth estimate of $0.4 \mathrm{~m}$ below palaeoMSL (Fig. 3 ).

The observed difference in the elevation of the lower shore platform compared with the upper marine units along the Western Australia coast has been variously attributed to localized tectonic uplift $^{13-15}$, isostatic deformation ${ }^{16}$, or changes in ice volume $e^{17,18}$. We have demonstrated, based on the near-uniform elevation of the lower palaeoMSL datum, that there seems to have been minimal tectonic uplift or subsidence along the Western Australia coast since the last interglacial (Cape Cuvier being an exception). Although an early MIS 5e age for the upper marine units would be indicative of a peak early isostatic highstand (plus a component of ESL rise), a late MIS 5e age can be indicative only of a eustatic jump in sea level. Therefore determining the age of the higher marine MIS 5e units relative to the age of the lower shore platform is critical to our understanding of sea-level variability and ice sheet sensitivity during MIS 5e.

Previous attempts ${ }^{15,18}$ to date the high-elevation corals proved inconclusive owing to either diagenetic effects and/or detrital ${ }^{232} \mathrm{Th}$ contamination. Here, a total of 21 new and previously published U-series coral dates, now screened for detrital Th $(>0.5 \mathrm{ppb})$ and corrected for open-system artefacts, returned a mean age of $118.1 \pm$ $1.4 \mathrm{kyr}$ (red samples in Fig. 3). We applied the same approach used in calculating the lower palaeoMSL datum to the upper marine units and were able to establish a minimum peak palaeoMSL highstand of +8.2 m late in MIS 5e. The GIA correction to these elevations would be essentially the same as the correction applied to the 119-kyr-old shorelines (for example, $8.2 \mathrm{~m}+0.9 \mathrm{~m}=9.1 \mathrm{~m}$ ), thus these data strongly support a rapid $\sim 6 \mathrm{~m}$ rise $(9.1 \mathrm{~m}-3.4 \mathrm{~m}=5.7 \mathrm{~m})$ in local sea level along the coast of Western Australia in the later part of MIS 5e (Fig. 3). Modelling indicates that the eustatic value of the associated ice sheet melting was probably $\sim 10 \%$ lower than the local sea-level rise (or $\sim 5 \mathrm{~m}$; Supplementary Fig. S3).

At Red Bluff, two corals collected at +6.1 and $+6.8 \mathrm{~m}$ above MSL yield ages that are too old to be associated with the high stand $118 \mathrm{kyr}$ ago (these are the brown dots between 126 and $128 \mathrm{kyr}$ ago on Fig. 3). It may be that these corals grew during the early highstand predicted by GIA models (Fig. 3), a proposition supported by geomorphic field relationships as both corals were collected from the innermost and highest section of the reef at Red Bluff and form a thin veneer on top of an older limestone foundation.

A single encrusting coral collected from $+9.2 \mathrm{~m}$ at Camp Rock returned replicate ages of 124.7 and $125.4 \mathrm{kyr}$ (Fig. 3 ). This would suggest a rapid $3 \mathrm{~m}$ (taking into account $1 \mathrm{~m}$ of tectonic uplift at this site) rise and fall in sea level at this time. Although this would seem to be inconsistent with the observed development of the mature MIS 5e reef platforms along the length of the Western Australia Coast (which would have required an extended interval of gradually falling sea level to have formed), several studies including the Red Sea $\delta^{18} \mathrm{O}$ record ${ }^{19}$ and U-series coral data from Barbados ${ }^{20}$ do show evidence for variable sea levels during early/middle MIS 5e. Continued investigation of the geomorphic development of shore platforms in terms of rates of horizontal erosion and vertical down cutting, together with refined dating of corals collected from this higher marine unit, will be required to better constrain the timing and peak amplitude of sea level during this early phase of MIS 5e in Western Australia.

\section{Implications for ice sheet stabilty}

Based on our survey of Western Australia we conclude (with important caveats noted above) that a prolonged period of relatively stable ESL, 3-4 $\mathrm{m}$ above the present level, occurred between 127 and $119 \mathrm{kyr}$ ago. Stable ice volume, in combination with a moderate, $\sim 3 \mathrm{~m}$, relative sea-level fall associated with GIA across this interval (Supplementary Fig. S2) resulted in a sea-level curve of the form shown in Fig. 3. This phase was characterized by sea-level-constrained, laterally prograding, fringing reefs and the development of an associated erosional shore platform forming the upper surface. Evidence for a subsequent, rapid rise in sea level in Western Australia is expressed in the geomorphology and stratigraphy of younger upper marine units, which suggest flooding and re-establishment of coral and encrusting algal growth up to a palaeoMSL elevation of $+8.2 \mathrm{~m}$ (Fig. 3 ). U-series dating constrains the timing of this peak MIS 5e sea-level event to $118.1 \pm 1.4 \mathrm{kyr}$ ago, consistent with earlier arguments that a late MIS 5e highstand was driven by ice volume changes ${ }^{17,21-23}$.

The two-stage melting scenario inferred from our analysis of sea-level records from Western Australia suggests the ice sheets may have many interglacial steady states with inherent tipping points that can lead to rapid ice sheet collapse and transitions between states. In this regard, our inferred rise in ESL near the end of MIS $5 \mathrm{e}$ is twice the estimate of a $\sim 3 \mathrm{~m}$ jump based on geological data from the Yucatan ${ }^{24}$. Moreover, our inference that peak ESL reached $\sim 9 \mathrm{~m}$ higher than present during MIS $5 \mathrm{e}$ is at the upper bound of two other recent inferences ${ }^{5,25}$. Furthermore, recently published data from the North Greenland Eemian (NEEM) ice core record show a maximum $2 \mathrm{~m}$ eustatic component from the Greenland Ice Sheet during MIS 5e (ref. 26), this would suggest a greater eustatic contribution from the West Antarctic and possibly East Antarctic ice sheets at this time. Resolving discrepancies between various field and modelling studies as well as explaining the detailed temporal connection between climate and global ice volume will be crucial to improving our understanding of ice sheet stability not only during interglacial periods such as MIS 5e, but also in our progressively warming world.

\section{Methods}

Survey methods. An OmniSTAR-HP differential global positioning system with an internal vertical precision of $\pm 10 \mathrm{~cm}$ was used to survey sites. All measurements are taken from the Australian Height Datum (AHD) zero datum level, which is equivalent to MSL. Previously surveyed sites were resurveyed with elevations 
corrected to the AHD. Therefore, any differences in palaeoshoreline elevation between this and previous studies will simply represent the difference in elevation between the MLLW datum and the AHD datum used here.

U-series dating. New and previously published coral ages from Western Australia were screened on the basis of detrital ${ }^{232} \mathrm{Th}>0.5 \mathrm{ppb}$ and low internal precision with age errors $>3 \mathrm{kyr}$. Corals that passed this initial screening were corrected for open-system artefacts using the protocols described in ref. 27. Those open-system-corrected coral ages that fell outside the published duration of MIS 5e, 130-114 kyr, were also omitted.

GIA modelling. We used a gravitationally self-consistent theory ${ }^{28}$ that incorporates: time-varying shorelines owing to local onlap or offlap of water; the growth and melting of grounded, marine-based ice sheets and the associated migration of water into or out of these marine settings; and the feedback into sea level of contemporaneous perturbations in the Earth's rotation vector. The sea-leve predictions require two inputs. The first is a model for the space-time geometry of global ice cover. In this regard, our simulations incorporate two glacial cycles, both adapted from the global ICE-5G model for the last glacial cycle ${ }^{29}$. The calculations assume that ice volumes during MIS5e are identical to the present day. The second input into the sea-level prediction is the radial profile of mantle viscosity. To begin we adopt a test Earth model characterized by a high-viscosity (effectively elastic) lithosphere of thickness $70 \mathrm{~km}$ and constant viscosities of $5 \times 10^{20} \mathrm{~Pa}$ s in the upper mantle and $10^{22} \mathrm{~Pa}$ in the lower mantle. This model is broadly consistent with a range of ice age observables ${ }^{30,31}$, including late Holocene sea-level records in Australia ${ }^{10}$. We also consider the sensitivity of the GIA predictions to variations in the parameters that define this model.

\section{Received 29 January 2013; accepted 17 June 2013; published online} 28 July 2013

\section{References}

1. Lambeck, K. Sea-level change through the last glacial cycle: Geophysical, glaciological and palaeogeographic consequences. Comptes Rendus Geosci. 336, 677-689 (2004).

2. Peltier, W. R. \& Fairbanks, R. G. Global glacial ice volume and Last Glacial Maximum duration from an extended Barbados sea level record. Quat. Sci. Rev. 25, 3322-3337 (2006).

3. Milne, G. A. \& Mitrovica, J. X. Searching for eustasy in deglacial sea-level histories. Quat. Sci. Rev. 27, 2292-2302 (2008).

4. Mitrovica, J. X. \& Milne, G. A. On the origin of late Holocene sea-level highstands within equatorial ocean basins. Quat. Sci. Rev. 21, 2179-2190 (2002)

5. Dutton, A. \& Lambeck, K. Ice volume and sea level during the last interglacial. Science 337, 216-219 (2012).

6. Kennedy, D. M., Marsters, T. H., Woods, J. L. D. \& Woodroffe, C. D. Shore platform development on an uplifting limestone island over multiple sea-level cycles, Niue, South Pacific. Geomorphology 141-142, 170-182 (2012).

7. Hearty, P. J., Neumann, A. C. \& O'Leary, M. Comment on 'Record of MIS 5 sea-level highstands based on U/Th dated coral terraces of Haiti' by Dumas et al. [Quaternary International 2006 106-118]. Quat. Int. 162, 205-208 (2007).

8. Thompson, W. G., Curran, H. A., Wilson, M. A. \& White, B. Sea-level oscillations during the last interglacial highstand recorded by Bahamas corals. Nature Geosci. 4, 684-687 (2011).

9. Lambeck, K., Purcell, A. \& Dutton, A. The anatomy of interglacial sea levels: The relationship between sea levels and ice volumes during the Last Interglacial. Earth Planet. Sci. Lett. 315, 1-8 (2011).

10. Nakada, M. \& Lambeck, K. Late Pleistocene and Holocene sea-level change in the Australian region and mantle rheology. Geophys. J. Int. 96, 497-517 (1989).

11. Raymo, M. E. \& Mitrovica, J. X. Collapse of polar ice sheets during the stage 11 interglacial. Nature 483, 453-455 (2012).

12. Mckay, N. P., Overpeck, J. T. \& Otto-Bliesner, B. L. The role of ocean thermal expansion in Last Interglacial sea level rise. Geophys. Res. Lett. 38, L14605 (2011)

13. Denman, P. D. \& van de Graaff, W. Emergent Quaternary marine deposits in the Lake MacLeod area, WA: Western Australia (Geol. Survey Ann. Rept 32-37, 1976).

14. Veeh, H., Schwebel, D., Van De Graaff, W. J. E. \& Denman, P. D. Uranium-series ages of coralline terrace deposits in Western Australia. Aust. J. Earth Sci. 26, 285-292 (1979).

15. Stirling, C. H., Esat, T. M., Lambeck, K. \& Mcculloch, M. T. Timing and duration of the Last Interglacial: Evidence for a restricted interval of widespread coral reef growth. Earth Planet. Sci. Lett. 160, 745-762 (1998).
16. Lambeck, K. \& Nakada, M. Constraints on the age and duration of the last interglacial period and on sea-level variations. Nature 357, 125-128 (1992).

17. Hearty, P. J., Hollin, J. T., Neumann, A. C., O'Leary, M. J. \& McCulloch, M. Global sea-level fluctuations during the Last Interglaciation (MIS 5e). Quat. Sci. Rev. 26, 2090-2112 (2007).

18. O'Leary, M., Hearty, P. J. \& McCulloch, M. T. Geomorphic evidence of major sea-level fluctuations during marine isotope substage-5e, Cape Cuvier, Western Australia. Geomorphology 102, 595-602 (2008).

19. Rohling, E.J. et al. High rates of sea-level rise during the last interglacial period. Nature Geosci. 1, 38-42 (2008).

20. Thompson, W. G. \& Goldstein, S. L. Open-system coral ages reveal persistent suborbital sea-level cycles. Science 308, 401-404 (2005).

21. Land, L. S., Mackenzie, F. T. \& Gould, S. J. Pleistocene history of Bermuda. Geol. Soc. Am. Bull. 78, 993-1006 (1967).

22. Hollin, J. T. Thames interglacial sites, Ipswichian sea levels and Antarctic ice surges. Boreas 6, 33-52 (1977).

23. Neumann, A. C. \& Hearty, P. Rapid sea-level changes at the close of the last interglacial (substage 5e) recorded in Bahamian island geology. Geology 24, 775-778 (1996).

24. Blanchon, P., Eisenhauer, A., Fietzke, J. \& Liebetrau, V. Rapid sea-level rise and reef back-stepping at the close of the last interglacial highstand. Nature 458, 881-U6 (2009).

25. Kopp, R. E., Simons, F. J., Mitrovica, J. X., Maloof, A. C. \& Oppenheimer, M. Probabilistic assessment of sea level during the last interglacial stage. Nature 462, 863-U51 (2009).

26. Dahl-Jensen, D. et al. Eemian interglacial reconstructed from a Greenland folded ice core. Nature 493, 489-494 (2013).

27. Thompson, W. G., Spiegelman, M., Goldstein, S. L. \& Speed, R. An open-system model for U-series age determinations of fossil corals. Earth Planet. Sci. Lett. 210, 365-381 (2003).

28. Kendall, R. A., Mitrovica, J. X. \& Milne, G. A. On post-glacial sea level-II. Numerical formulation and comparative results on spherically symmetric models. Geophys. J. Int. 161, 679-706 (2005).

29. Peltier, W. R. Global glacial isostasy and the surface of the ice-age Earth: The ICE-5G (VM2) model and GRACE. Annu. Rev. Earth Planet. Sci. 32, $111-149$ (2004)

30. Lambeck, K., Smither, C. \& Johnston, P. Sea-level change, glacial rebound and mantle viscosity for northern Europe. Geophys. J. Int. 134, 102-144 (1998).

31. Mitrovica, J. X. \& Forte, A. M. A new inference of mantle viscosity based upon joint inversion of convection and glacial isostatic adjustment data. Earth Planet. Sci. Lett. 225, 177-189 (2004).

\section{Acknowledgements}

This study of MIS 5e sea level is the product of more than ten years of research and collaboration among the authors and others not mentioned. We thank Omnistar's Perth office for providing the global positioning system satellite signal. Our work was also supported by NSF award OCE1202632 to M.E.R., P.J.H., and J.X.M.; NSF awards OCE0602383, EAR0819714 and OCE0902849 to W.G.T.; ARC award DP0209059 to M. McCulloch, P.J.H. and A. Halliday; the Canadian Institute for Advanced Research and Harvard University (J.X.M.); and M. Gagnon, Curtin University.

\section{Author contributions}

M.J.O. contributed to the field mapping and provided the geochronology, including mass spectrometry and age interpretations. He also provided GIA interpretations and wrote the manuscript. P.J.H. contributed to the field mapping and stratigraphic interpretations and assisted in the writing of the manuscript. W.G.T. contributed to the field mapping, provided the geochronology, including mass spectrometry and age interpretations, and assisted in the writing of the manuscript. M.E.R. contributed to the field mapping, provided GIA interpretations and assisted in the writing of the manuscript. J.X.M. carried out the GIA modelling, including interpretations, and assisted in the writing of the manuscript. J.M.W. contributed to stratigraphic and geomorphic field-mapping interpretations.

\section{Additional information}

Supplementary information is available in the online version of the paper. Reprints and permissions information is available online at www.nature.com/reprints. Correspondence and requests for materials should be addressed to M.J.O.

\section{Competing financial interests}

The authors declare no competing financial interests. 